(2) Open Access Full Text Article

REVIEW

\title{
Crizotinib as a personalized alternative for targeted anaplastic lymphoma kinase rearrangement in previously treated patients with non-small-cell lung cancer
}

This article was published in the following Dove Press journal:

Drug Design, Development and Therapy

3 October 2015

Number of times this article has been viewed

\author{
Liting Guol,* \\ Haijun Zhangl,* \\ Weiwei Shao ${ }^{2}$ \\ Baoan Chen' \\ 'Department of Hematology and \\ Oncology (Key Department of Jiangsu \\ Medicine), The Affiliated Zhongda \\ Hospital, Medical School of Southeast \\ University, Nanjing, ${ }^{2}$ Department of \\ Pathology, the First People's Hospital \\ of Yancheng, Yancheng, Jiangsu, People's \\ Republic of China
}

*These authors contributed equally to this work

\begin{abstract}
Crizotinib, the first clinically designed and synthesized as a tyrosine kinase inhibitor targeting mesenchymal-epithelial transition factor, indicating marked anticancer activity in patients with advanced, anaplastic lymphoma kinase-positive non-small-cell lung cancer, was approved by the US Food and Drug Administration in 2011. In this review, we focus on the efficacy of crizotinib compared with chemotherapy in advanced anaplastic lymphoma kinasepositive lung cancer and present the role of crizotinib as a personalized alternative in previously treated patients with non-small-cell lung cancer.
\end{abstract}

Keywords: crizotinib, anaplastic lymphoma kinase rearrangement, non-small-cell lung cancer

\section{Introduction}

Lung cancer is the most common cancer and the leading cause of tumor-related death worldwide, $\sim 85 \%-90 \%$ of which are characterized as non-small-cell lung cancer (NSCLC). ${ }^{1}$ For the treatments of lung cancer, the traditional methods include surgery, radiotherapy, and chemotherapy. The majority of patients $(68 \%)$ with early stage NSCLC undergo surgery, and 16\% patients also receive chemotherapy or radiation therapy. A total of $18 \%$ of patients with advanced-stage NSCLC are treated with chemotherapy alone, $15 \%$ radiation therapy alone, and 33\% a combination therapy. ${ }^{2}$ However, in recent years, targeted drugs shift the traditional treatment mode of NSCLC. This paradigm was first established with the discovery of epidermal growth factor receptor (EGFR), and EGFR tyrosine kinase inhibitors (TKIs) are excellent examples of personalized alternative. ${ }^{3}$ Anaplastic lymphoma kinase $(A L K)$, a member of the insulin receptor family of receptor tyrosine kinases (RTKs), as a fusion oncogene with nucleophosmin, was first identified in anaplastic large-cell lymphomas on chromosome $2 \mathrm{p} 23 .{ }^{4}$ $A L K$ encodes a 1,620-amino acid transmembrane protein, including an extracellular ligand-binding domain, a transmembrane domain, and an intracellular kinase catalytic region. ${ }^{5}$ Echinoderm microtubule-associated protein-like 4 (EML4) is an intracellular protein of $120 \mathrm{kDa}$, a member of echinoderm microtubule-associated protein family and microtubule stabilizing protein, and plays the role in the formation of microtubules. 5,6 $E M L 4-A L K$ fusion gene is a new gene mutation, which is closely related to the growth and proliferation of tumor cells. Soda et $\mathrm{al}^{7}$ identified the transforming EML4-ALK fusion gene in $6.7 \%$ of patients with NSCLC, resulting from a small inversion within the short arm of chromosome $2 \mathrm{p}(2 \mathrm{p} 21$ and $2 \mathrm{p} 23)$, which produces a fusion protein consisting
Correspondence: Baoan Chen Department of Hematology and Oncology (Key Department of Jiangsu Medicine), The Affiliated Zhongda Hospital, Medical School of Southeast University, Dingjiaqiao 87, Gulou District, Nanjing 210009, Jiangsu Province,

People's Republic of China

Tel +862583272006

Fax +86258327 20I I

Email cba8888@hotmail.com 
of the amino-terminal protein of EML4 and the intracellular region tyrosine kinase $A L K{ }^{8}$ It is the most common $A L K$ fusion gene in patients with NSCLC, and the clinical characteristics of these individuals are significantly distinct from $E G F R$-positive patients. ${ }^{7}$ One of the distinctive clinicopathological features is more prevalent in the fluorescence in situ hybridization (FISH)-positive $A L K$ rearrangement patients with the history of never smoked or a light smoking $(<10$ pack-years), and the other includes younger age at diagnosis and adenocarcinoma histologic analyses associated with $A L K$ positive lung cancers. ${ }^{9} E M L 4-A L K$-positive lung adenocarcinomas were less-differentiated grade and acinar-predominant structure observed by histology. ${ }^{10}$ Furthermore, EML4-ALK expression was mutually exclusive with $E G F R$ and $K R A S$ mutations in sufficient tissues. ${ }^{10,11} A L K$ gene rearrangements or the resulting fusion proteins in NSCLC can be detected in tumor specimens using FISH, reverse transcriptase polymerase chain reaction, and immunohistochemistry. ${ }^{12}$ NSCLC tissues harboring $A L K$ gene rearrangements are representing $3 \%-5 \%$ and define a distinct molecular subgroup of the tumor; a total of $>60,000$ new cases with $A L K$-positive are projected to occur in NSCLC annually. 5,13

Crizotinib (PF-02341066, trade name Xalkori; Pfizer Inc., New York, NY, USA), the first clinically designed and synthesized as a TKI targeting mesenchymal-epithelial transition factor (c-Met), also called MET and hepatocyte growth factor receptor, indicating marked anticancer activity in patients with advanced, $A L K$-positive NSCLC, was approved by the US Food and Drug Administration in 2011. ${ }^{14-17}$ In this article, the structure, mechanism, pharmacokinetics, and pharmacogenetics of crizotinib are reviewed. We have also summarized the efficacy of crizotinib compared with chemotherapy in advanced $A L K$-positive lung cancer and presented the role of crizotinib as personalized alternative in previously treated patients with NSCLC.

\section{Structure, mechanism, and pharmacokinetics Structure of crizotinib}

Crizotinib as multitargeted TKI is a small molecule (molecular weight $=450 \mathrm{Da}),{ }^{18}$ oral, highly selective and potent competitive inhibitor of $A L K$ with additional MET, c-ros oncogene (ROS1), and recepteur d'origine nantais kinase inhibitory property. ${ }^{16,19}$ Molecular formula of crizotinib is $\mathrm{C}_{21} \mathrm{H}_{22} \mathrm{C}_{12} \mathrm{FN}_{5} \mathrm{O}$, and the chemical formula is $(R)-3$-[1-(2,6-dichloro-3-fluorophenyl) ethoxy]-5-[1-(piperidin-4-yl)-1H-pyrazol-4-1] pyridine-2amine, which is shown in Figure $1{ }^{20}$

\section{Mechanism}

In biochemical and cellular screens for kinase selectivity, crizotinib was shown to be selective for $c$-Met and $A L K$ with high potency and specificity across a panel of $>120$ diverse

\section{A}

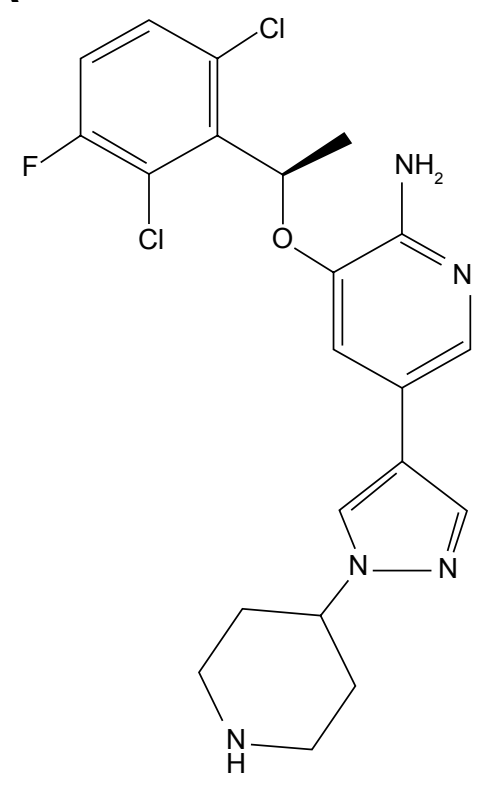

B

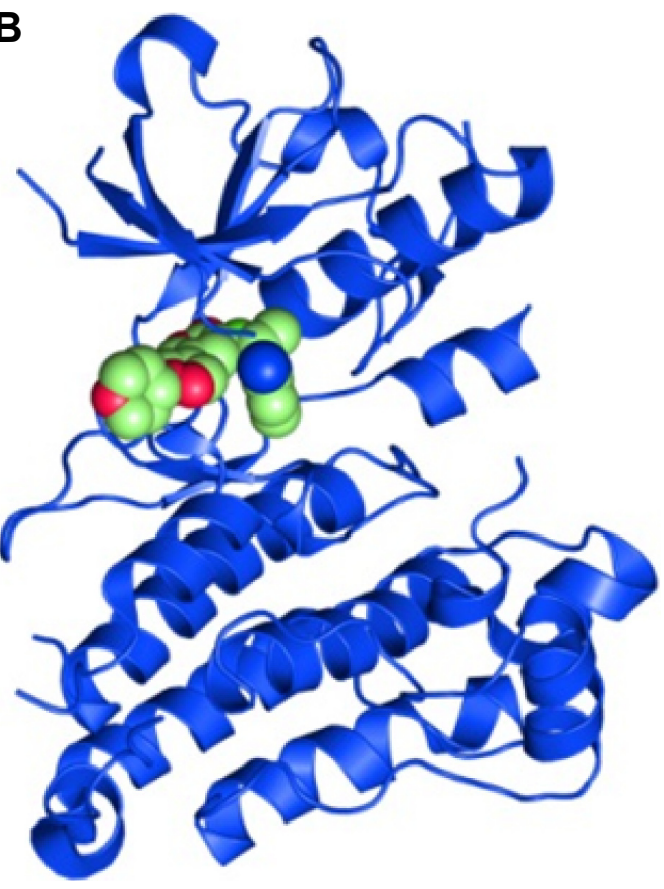

Figure I Chemical structure of crizotinib (A) and ALK in complex with crizotinib (B). Abbreviation: $A L K$, anaplastic lymphoma kinase. 
kinases. ${ }^{21,22}$ A chromosomal inversion on chromosome $2 \mathrm{p}$ leads to an aberrant $E M L 4-A L K$ fusion oncogene in NSCLC. Thus, $A L K$ tyrosine kinase is constitutively activated, leading to uncontrolled cell growth and proliferation through activation of phosphoinositide 3-kinase and mitogen-activated protein kinase. ${ }^{20}$ Apoptosis in EML4-ALK NSCLC cell lines and tumor shrinkage in murine models were observed when $A L K$ kinase activity was inhibited via small-molecule $A L K$ kinase inhibitors. ${ }^{22}$ Crizotinib potently inhibited cell proliferation, which was associated with G1-S-phase cell cycle arrest and induction of apoptosis in $A L K$-positive anaplastic large-cell lymphomas cells but not $A L K$-negative lymphoma cells. ${ }^{23}$ Crizotinib dose dependently inhibited the phosphorylation of $c$-Met and $A L K$ and effectively inhibited downstream effector functions in vitro and in vivo. ${ }^{19,24}$

\section{Pharmacokinetics and pharmacogenetics}

Crizotinib was determined orally as a capsule, and clinical studies indicated $250 \mathrm{mg}$ twice daily (bid) as the maximal tolerated dose in 167 patients with cancer. ${ }^{25,26}$ Peak plasma crizotinib concentrations were achieved 4-6 hours after absorption of a single dose of $250 \mathrm{mg}$. After repeated dosing at $250 \mathrm{mg}$ bid, steady-state concentrations were reached within 15 days. ${ }^{26}$ Bioavailability was $43 \%$ (range: $32 \%-66 \%$ ) and crizotinib exposure was influenced by food only to a minor degree. ${ }^{20,25}$ Age, sex, race, or body weight appeared to have no effects on the single-dose crizotinib. ${ }^{26}$ Crizotinib treated in $A L K$-positive NSCLC patients was similar to patients with other cancer types of pharmacokinetic parameters. Mean values for crizotinib peak plasma concentrations $\left(C_{\max }\right)$ and area under the plasma concentration-time curve were greater in Asian patients than in non-Asian patients. ${ }^{20,26,27}$ Metabolization was executed primarily by cytochrome P450 3A4/5 enzymes, resulting in time-dependent inhibition of cytochrome P450 3A4 under extensive hepatic metabolism. Furthermore, crizotinib was also modulated by other drugs interacting with this cytochrome oxidase..$^{20,25}$ The lifetime incidence of central nervous system (CNS) disease in patients with advanced $A L K$-positive NSCLC approaches $50 \% .{ }^{28}$ However, crizotinib and the other small-molecule TKIs, including imatinib, erlotinib, and gefitinib, had the low penetration of the cerebrospinal fluid ${ }^{29}$ and may require alternative dosing schemes or increased dose adjustments. ${ }^{30}$ Local ablative therapy such as radiotherapy or surgery could be a strategy for systemic cancer control with continuation of crizotinib. ${ }^{29,31}$ PF-06463922 (developed by Pfizer), which is a novel multitargeted $A L K$ and ROS1 TKI, a low-efflux substrate from cell lines overexpressing P-glycoprotein was designed to increase potential CNS penetration. ${ }^{29,32}$ PF-06463922 exhibited superior potency against brain metastases compared with crizotinib and alectinib; a Phase I and II clinical trials of PF-06463922 is currently under way, and this drug can be effective in $A L K$-rearranged NSCLC patients with CNS disease in the crizotinib naïve or resistance. ${ }^{29,33}$

\section{Personalized alternative for targeted ALK-positive in previously treated patients with NSCLC}

The efficacy of crizotinib in the treatment of NSCLC has been investigated in several clinical trials, including various Phase I, II, and III studies on register (Table 1).

The first-in-man Phase I (PROFILE 1001) crizotinib trial (Funded by Pfizer and others, ClinicalTrials.gov number, NCT00585195), was designed as an open-label, multicenter dose-escalation study. ${ }^{9,34,35}$ The trial consisted of a subgroup of 82 patients with advanced $A L K$-positive NSCLC confirmed by FISH. ${ }^{14}$ The majority of the patients had received previous treatment. The dose-limiting toxicity was defined at $300 \mathrm{mg}$ bid, in which two patients experienced grade 3 fatigue, and the maximum tolerated dose and recommended Phase II dose were defined at $250 \mathrm{mg}$ bid in 28-day cycles. ${ }^{17,36,37}$ After the mean duration 6.4 months of

Table I Characteristics of the clinical studies of crizotinib

\begin{tabular}{|c|c|c|c|c|c|c|}
\hline Study & Trial & ID & Design & Number & PFS (months) & ORR (\%) \\
\hline Kwak et al9 & Phase I & PROFILE I00I & Single arm & 149 & 9.7 & 60.8 \\
\hline \multicolumn{7}{|l|}{ Camidge et $\mathrm{al}^{17}$} \\
\hline Crinò et $\mathrm{al}^{40}$ & Phase II & PROFILE I005 & Single arm & 259 & 8.5 & 53 \\
\hline \multicolumn{7}{|l|}{ Kim et $\mathrm{al}^{41}$} \\
\hline \multirow[t]{3}{*}{ Shaw et $\mathrm{al}^{13}$} & Phase III & PROFILE I007 & Second line & 347 & 7.7 & 65 \\
\hline & & & Crizotinib vs pemetrexed & & & \\
\hline & & & or docetaxel & & & \\
\hline \multirow[t]{3}{*}{ Solomon et $\mathrm{al}^{44}$} & Phase III & PROFILE I0I4 & First line & 343 & 10.9 & 74 \\
\hline & & & Crizotinib vs pemetrexed/cisplatin & & & \\
\hline & & & or carboplatin & & & \\
\hline
\end{tabular}

Abbreviations: PFS, progression-free survival; ORR, objective response rate; ID, identification. 
the treatment, an objective response rate (ORR) of 57\% (95\% confidence interval $=46-68)$ was observed in the cohort. An additional group of 27 (33\%) patients showed stable disease and $63(77 \%)$ patients were still receiving treatment, and the estimated progression-free survival (PFS) at 6 months was $72 \%{ }^{9,14}$ Based on these promising data, an expanded cohort of patients with $A L K$-positive NSCLC was subsequently enrolled. ${ }^{17,38}$ The expansion of this trial recruited additional population that consisted of 143 characteristic patients with $A L K$-positive lung cancer. The median age was 52 years, and the ORR was $60.8 \%$ (87 of 143 evaluable patients), including three patients with a complete response (CR) and 84 with a partial response (PR). ${ }^{17,39}$ The estimated median PFS was 9.7 months for all patients, and the median duration of response was 49.1 weeks, regardless of age, sex, and performance status. Median overall survival (OS) data are not yet mature, but the estimated 6-month and 12-month OS rates were $88 \%$ and $75 \%$, respectively. ${ }^{17}$

Similar impressive clinical activity of crizotinib was observed in an ongoing global Phase II study (PROFILE 1005, NCT00932451) of advanced, $A L K$-positive NSCLC. ${ }^{15}$ The efficacy of open-label, single-arm Phase II trial with crizotinib has been assessed in 136 patients who are $A L K$ positive. ${ }^{40}$ At the latest update, among 901 patients with $A L K$-positive NSCLC received crizotinib therapy, the ORR of 259 patients evaluable for response was $53 \%$, the CR in one patient and the PR in 67 patients, with median duration of response of 10.8 months and median PFS of 8.5 months. ORR was independent of age, sex, and number of prior metastatic treatment regimens. ${ }^{24,40-42}$ These studies accelerated approval for crizotinib in $A L K$-rearranged NSCLC in many countries and granted by the US Food and Drug Administration. ${ }^{17,43}$

Recently, the results of two international, randomized Phase III studies of crizotinib were conducted. ${ }^{15}$ The first Phase III trial (the second-line trial, PROFILE 1007) compared crizotinib with chemotherapy (single-agent pemetrexed or docetaxel) in 347 patients (173 to crizotinib and 174 to chemotherapy) with advanced $A L K$-positive NSCLC detected by FISH who have received one prior platinumbased chemotherapy. ${ }^{13-15}$ PFS was the primary end point in the study, with OS as a secondary end point. ${ }^{15}$ PFS was prolonged in the crizotinib-treated group, with the median PFS of 7.7 months in the crizotinib group and 3.0 months in the chemotherapy group. The response rate was also obviously higher in patients treated with crizotinib $(65 \%)$ as compared with chemotherapy (20\%). However, there was no significant difference in OS between crizotinib and chemotherapy, and $64 \%$ of patients on chemotherapy crossed
Table 2 The efficacy of crizotinib compared with standard chemotherapy in previously treated patients with NSCLC

\begin{tabular}{lll}
\hline Efficacy parameter & $\begin{array}{l}\text { Crizotinib } \\
(\mathbf{N}=\mathbf{I 7 3})\end{array}$ & $\begin{array}{l}\text { Pemetrexed or } \\
\text { docetaxel }(\mathbf{N}=\mathbf{I 7 4})\end{array}$ \\
\hline PFS (months) $(95 \% \mathrm{Cl})$ & $7.7(6.0-8.8)$ & $3.0(2.6-4.3)$ \\
$\begin{array}{l}\text { ORR (\%) }(95 \% \mathrm{Cl}) \\
\begin{array}{l}\text { Median duration of } \\
\text { response (weeks) (range) }\end{array}\end{array}$ & $65(58-72)$ & $20(14-26)$ \\
$\begin{array}{l}\text { Median time to } \\
\text { response (weeks) (range) }\end{array}$ & $6.3(4.1-72.4)$ & $24.4(3.0-43.6)$ \\
\hline
\end{tabular}

Abbreviations: NSCLC, non-small-cell lung cancer; PFS, progression-free survival; $\mathrm{Cl}$, confidence interval; ORR, objective response rate.

over to crizotinib at disease progression probably influenced the data. ${ }^{13}$ Crizotinib is superior to standard chemotherapy in patients with previously treated NSCLC with $A L K$ rearrangement (Table 2).

The second Phase III trial (The first-line trial, PROFILE 1014) is ongoing, comparing crizotinib with standard chemotherapy (pemetrexed plus either cisplatin or carboplatin) in newly diagnosed 343 patients with $A L K$-positive advanced NSCLC. PFS of crizotinib and standard chemotherapy was 10.9 months and 7.0 months, respectively. The ORR showed superiority of crizotinib over first-line chemotherapy.

The probability of 1-year survival was $84 \%$ with crizotinib and $79 \%$ with chemotherapy. ${ }^{44}$ In addition, ROS1 (chromosome 6q22) encodes an orphan RTK related to $A L K$ and belongs to the insulin receptor family. ${ }^{45}$ Chromosomal rearrangements involving the ROS1 RTK gene have been reported in a subgroup of NSCLC patients, which occurs in $\sim 1 \%-2 \%$ of patients with NSCLC. ${ }^{46-48}$ All of the ROS1-positive NSCLCs were remarkably similar to that of $A L K$-rearranged patients, who have histologic features of adenocarcinoma, a tendency toward higher grade, young age, and never smoked. The preclinical study indicated that crizotinib could inhibit ROS1 activity and cell growth in vitro. ${ }^{45}$ In an expansion cohort of the Phase I study (250 mg twice daily) in 50 previously treated patients with ROS1-positive rearrangement advanced NSCLC, the ORR was $72 \%$, including three CRs and 33 PRs. The median duration of response was 17.6 months, and median PFS was 19.2 months, with 25 patients (50\%) still in follow-up for progression. ${ }^{46} \mathrm{ROS} 1$-rearangement could be a predictive marker for response to crizotinib; furthermore, it seems as the prognostic molecular marker in NSCLC. ${ }^{48}$

\section{Safety and adverse effect}

Crizotinib was generally well tolerated with the majority of adverse events (AEs), the most of which are moderate (grade 1 or 2). The frequently occurring AEs were visual effects (visual impairment, photopsia, blurred vision, vitreous floaters, photophobia, and diplopia), but the visual disorders 
could disappear after discontinuation of crizotinib. Other common AEs included fatigue, decreased appetite, gastrointestinal events (nausea, diarrhea, vomiting, and constipation), peripheral edema, esophageal disorders (dyspepsia, esophagitis, and gastroesophageal reflux), altered taste, neuropathy, dizziness, and rash. , $^{9,40,41,44}$

\section{Resistance to crizotinib}

Despite the excellent efficacy, the majority of patients relapse during the first year of treatment and become resistant to crizotinib. ${ }^{15}$ Mechanisms of the acquired crizotinib resistance can be divided into two main classes. ${ }^{12}$ First, the target gene itself can be altered either by mutation or amplification, making tumor cells limit the drug efficacy to inhibit the kinase. ${ }^{35}$ Choi et $\mathrm{al}^{49}$ reported the two secondary mutations ( $C 1156 \mathrm{Y}$ and $L 1196 M$ ) within the kinase domain of EML4-ALK in tumor cells, $L 1196 M$ representing gatekeeper mutation that interferes with the binding of crizotinib and EML4-ALK, and the same $L 1196 M$ gatekeeper mutation was identified in a patient with acquired resistance. ${ }^{50,51}$ Second, crizotinib resistance is caused by the activation of alternative signaling pathways or so-called bypass tracks in $A L K$-positive NSCLCs. As an example, activation of EGFR signaling as a bypass signaling made resistant to crizotinib, suggesting that EGFR and some of its ligands may be upregulated. ${ }^{15,52}$ Katayama et $\mathrm{al}^{53}$ also identified aberrant activation of other kinases including marked amplification of KIT and increased autophosphorylation of EGFR in drug-resistant tumors from patients. Finally, $A L K$-positive NSCLC occurs through somatic kinase domain mutations, $A L K$ gene fusion copy number gain, and emergence of separate oncogenic drivers, which could represent a potential resistance mechanism. ${ }^{54}$

\section{Next-generation ALK inhibitors}

Ceritinib (Zykadia; Novartis International AG, Basel, Switzerland; formerly called LDK378) is an orally available, potent, small molecule TKI of $A L K$, and it is effective in preclinical models of $A L K$-positive NSCLC. ${ }^{55,56}$ Ceritinib has demonstrated antitumor activity in both crizotinib-naïve and crizotinib-refractory $A L K$-rearranged NSCLC patients. ${ }^{57}$ In particular, ceritinib increased activity against $A L K$ harboring L1196M, G1269A, I1171T, and S1206Y mutations, but it was ineffective at inhibiting two crizotinib-resistant $A L K$ mutations, G1202R and F1174C. ${ }^{32,57}$ Alectinib (RO5424802/ $\mathrm{CH} 5424802)$, which is being developed by Roche, is potent, selective, and orally available $A L K$ inhibitor. It was first approved in multicenter, single-arm, open-label, Phase I and II study of Japan. ${ }^{32,58}$ Based on the results of the study, alectinib could be an effective and safe option for the treatment of $A L K$-rearranged NSCLC, and it can be used to achieve strong and longlasting inhibitory effects on brain metastases. ${ }^{58,59}$ Currently, a clinical study (NCT01588028) assessing the activity of alectinib in patients who failed to respond to crizotinib-based treatment is ongoing. ${ }^{58}$ Brigatinib (previously known as AP26113) is a more potent inhibitor of $A L K$ than crizotinib and has activity against $A L K$ kinase domain mutations that confer resistance to crizotinib. ${ }^{31}$ Brigatinib has been shown to be effective for intracranial metastasis. ${ }^{59}$ Other $A L K$ inhibitors, such as PF-06463922 (Pfizer), X-396 (Xcovery, Holding Co LLC, West Palm Beach, FL, USA), ASP3026 (Astellas Pharma Inc., Tokyo, Japan), TSR-011 (Tesaro, Inc., Waltham, MA, USA), and CEP-37440 (TEVA, Petah Tikva, Israel), are in various stages of clinical development for $A L K$-positive cancers. ${ }^{31,32}$ Next-generation $A L K$ inhibitors including ceritinib, alectinib, and brigatinib in patients have seen impressive and durable responses progressing after crizotinib, indicating that these drugs represent effective second-line treatment options. ${ }^{31}$ Now, a number of effective treatment options raise for patients with $A L K$-rearranged NSCLC, what sequence to use these $A L K$ inhibitors is yet to be determined. ${ }^{31,32}$

\section{Heat shock protein $\mathbf{9 0}$ inhibitors}

Heat shock protein 90 (Hsp90) is a molecular chaperone involved in normal cellular functions as well as tumorigenesis, which has been identified as potential anticancer agents. ${ }^{32,60}$ Hsp90 inhibitors also showed efficacy in treating $A L K$-positive NSCLC; compared with TKIs, Hsp90 inhibitors appear to have lower response rates and side effects that are less tolerable. ${ }^{32}$ However, Hsp90 inhibitors had limited activity against CNS metastatic tumors. The present studies encourage patients to participate in clinical trials to address the best combination or treatment strategy of Hsp90 inhibitors. ${ }^{60}$ Immunotherapy through inhibition of programmed death 1 has demonstrated efficacy in treating advanced NSCLC. ${ }^{31,61}$ Ongoing trials will further define the utility of Hsp90 inhibitors in NSCLC. ${ }^{62}$

\section{Conclusion and future directions for drug development}

Crizotinib is a promising antitumor activity for patients with $A L K$ gene rearrangements in NSCLC. The clinical trials showed that crizotinib prolonged PFS, increased response rates, and improved the quality of life in patients. Crizotinib was superior to standard chemotherapy in patients with $A L K$-positive advanced NSCLC. Crizotinib for targeted $A L K$ rearrangement in previously treated patients with NSCLC brings us one step closer to personalized lung cancer therapy. Though crizotinib 
is well benefited for most patients who are $A L K$ positive, some still go on to relapse as a result of the acquired resistance. The multiple therapeutics strategies should be implemented and developed to overcome crizotinib resistance in the future.

\section{Acknowledgments}

This work was supported by the National Key Basic Research Program 973 of the People's Republic of China (number 2010CB732404), the National Nature Science Foundation of the People's Republic of China (numbers 81170492 and 81370673), and the National High Technology Research and Development Program 863 Projects of the People's Republic of China (number 2012AA022703).

\section{Disclosure}

The authors report no conflicts of interest in this work.

\section{References}

1. Thomas A, Liu SV, Subramaniam DS, Giaccone G. Refining the treatment of NSCLC according to histological and molecular subtypes. Nat Rev Clin Oncol. 2015;12(9):511-526.

2. DeSantis CE, Lin CC, Mariotto AB, et al. Cancer treatment and survivorship statistics, 2014. CA Cancer J Clin. 2014;64(4):252-271.

3. Steuer CE, Ramalingam SS. Targeting EGFR in lung cancer: lessons learned and future perspectives. Mol Aspects Med. In press 2015.

4. Morris SW, Kirstein MN, Valentine MB, et al. Fusion of a kinase gene, ALK, to a nucleolar protein gene, NPM, in non-Hodgkin's lymphoma. Science. 1994;263(5151):1281-1284.

5. Solomon B, Varella-Garcia M, Camidge DR. ALK gene rearrangements: a new therapeutic target in a molecularly defined subset of non-small cell lung cancer. J Thorac Oncol. 2009;4(12):1450-1454.

6. Houtman SH, Rutteman M, De Zeeuw CI, French PJ. Echinoderm microtubule-associated protein like protein 4 , a member of the echinoderm microtubule-associated protein family, stabilizes microtubules. Neuroscience. 2007;144(4):1373-1382.

7. Soda M, Choi YL, Enomoto M, et al. Identification of the transforming EML4-ALK fusion gene in non-small-cell lung cancer. Nature. 2007;448(7153):561-566.

8. Soda M, Takada S, Takeuchi K, et al. A mouse model for EML4ALK-positive lung cancer. Proc Natl Acad Sci U S A. 2008;105(50): 19893-19897.

9. Kwak EL, Bang YJ, Camidge DR, et al. Anaplastic lymphoma kinase inhibition in non-small-cell lung cancer. N Engl J Med. 2010;363(18): 1693-1703.

10. Inamura $\mathrm{K}$, Takeuchi K, Togashi $\mathrm{Y}$, et al. EML4-ALK lung cancers are characterized by rare other mutations, a TTF-1 cell lineage, an acinar histology, and young onset. Mod Pathol. 2009;22(4):508-515.

11. Gainor JF, Varghese AM, Ou SH, et al. ALK rearrangements are mutually exclusive with mutations in EGFR or KRAS: an analysis of 1,683 patients with non-small cell lung cancer. Clin Cancer Res. 2013;19(15): 4273-4281.

12. Solomon B, Wilner KD, Shaw AT. Current status of targeted therapy for anaplastic lymphoma kinase-rearranged non-small cell lung cancer. Clin Pharmacol Ther. 2014;95(1):15-23.

13. Shaw AT, Kim DW, Nakagawa K, et al. Crizotinib versus chemotherapy in advanced ALK-positive lung cancer. N Engl J Med. 2013;368(25): 2385-2394.

14. Shaw AT, Yeap BY, Solomon BJ, et al. Effect of crizotinib on overall survival in patients with advanced non-small-cell lung cancer harbouring ALK gene rearrangement: a retrospective analysis. Lancet Oncol. 2011;12(11):1004-1012.
15. Shaw AT, Engelman JA. ALK in lung cancer: past, present, and future. J Clin Oncol. 2013;31(8):1105-1111.

16. Gridelli C, Peters S, Sgambato A, Casaluce F, Adjei AA, Ciardiello F. ALK inhibitors in the treatment of advanced NSCLC. Cancer Treat Rev. 2014;40(2):300-306.

17. Camidge DR, Bang YJ, Kwak EL, et al. Activity and safety of crizotinib in patients with ALK-positive non-small-cell lung cancer: updated results from a phase 1 study. Lancet Oncol. 2012;13(10):1011-1019.

18. Frampton JE. Crizotinib: a review of its use in the treatment of anaplastic lymphoma kinase-positive, advanced non-small cell lung cancer. Drugs. 2013;73(18):2031-2051.

19. Cui JJ, Tran-Dubé M, Shen H, et al. Structure based drug design of crizotinib (PF-02341066), a potent and selective dual inhibitor of mesenchymalepithelial transition factor (c-MET) kinase and anaplastic lymphoma kinase (ALK). J Med Chem. 2011;54(18):6342-6363.

20. O'Bryant CL, Wenger SD, Kim M, Thompson LA. Crizotinib: a new treatment option for ALK-positive non-small cell lung cancer. Ann Pharmacother. 2013;47(2):189-197.

21. Christensen JG, Zou HY, Arango ME, et al. Cytoreductive antitumor activity of PF-2341066, a novel inhibitor of anaplastic lymphoma kinase and c-Met, in experimental models of anaplastic large-cell lymphoma. Mol Cancer Ther. 2007;6:3314-3322.

22. Gandhi L, Jänne PA. Crizotinib for ALK-rearranged non-small cell lung cancer: a new targeted therapy for a new target. Clin Cancer Res. 2012;18(14):3737-3742.

23. Sasaki T, Jänne PA. New strategies for treatment of ALK-rearranged nonsmall cell lung cancers. Clin Cancer Res. 2011;17(23):7213-7218.

24. Curran MP. Crizotinib: in locally advanced or metastatic non-small cell lung cancer. Drugs. 2012;72(1):99-107.

25. Hamilton G, Rath B, Burghuber O. Pharmacokinetics of crizotinib in NSCLC patients. Expert Opin Drug Metab Toxicol. 2015;11(5): 835-842.

26. Kozloff MF, Martin LP, Krzakowski M, et al. Pharmacokinetics (PK) of crizotinib (PF-02341066) in patients with advanced non-small cell lung cancer (NSCLC) and other solid tumors. J Clin Oncol. 2011; 29(suppl):e13065.

27. Niu FY, Wu YL. Personalized treatment strategies for non-small-cell lung cancer in Chinese patients: the role of crizotinib. Onco Targets Ther. 2015;8:999-1007.

28. Narayanan V, Honce MJ, Mehrotra S, Camidge DR. Cystic brain metastases occurring in anaplastic lymphoma kinase gene rearranged nonsmall-cell lung cancer patients receiving crizotinib. Clin Lung Cancer. Epub 2015 Jul 30.

29. Costa DB, Shaw AT, Ou SH, et al. Clinical experience with crizotinib in patients with advanced ALK-rearranged non-small-cell lung cancer and brain metastases. J Clin Oncol. 2015;33(17):1881-1888.

30. Costa DB, Kobayashi S, Pandya SS, et al. CSF concentration of the anaplastic lymphoma kinase inhibitor crizotinib. J Clin Oncol. 2011; 29:e443-e445.

31. Cameron L, Solomon B. New treatment options for ALK-rearranged nonsmall cell lung cancer. Curr Treat Options Oncol. 2015;16(10):367.

32. Awad MM, Shaw AT. ALK inhibitors in non-small cell lung cancer: crizotinib and beyond. Clin Adv Hematol Oncol. 2014;12(7):429-439.

33. Zou HY, Friboulet L, Kodack DP, et al. PF-06463922, an ALK/ROS1 inhibitor, overcomes resistance to first and second generation ALK inhibitors in preclinical models. Cancer Cell. 2015;28(1):70-81.

34. Ou SH. Crizotinib: a novel and first-in-class multitargeted tyrosine kinase inhibitor for the treatment of anaplastic lymphoma kinase rearranged non-small cell lung cancer and beyond. Drug Des Devel Ther. 2011; 5:471-485.

35. Rothschild SI, Gautschi O. Crizotinib in the treatment of non-small-cell lung cancer. Clin Lung Cancer. 2013;14(5):473-480.

36. Kwak EL, Camidge DR, Clark J, et al. Clinical activity observed in a phase I dose escalation trial of an oral c-met and ALK inhibitor, PF-02341066. J Clin Oncol. 2009;27(suppl):148s.

37. Lazzari C, Spitaleri G, Catania C, et al. Targeting ALK in patients with advanced non small cell lung cancer: biology, diagnostic and therapeutic options. Crit Rev Oncol Hematol. 2014;89(3):358-365. 
38. Iacono D, Chiari R, Metro G, et al. Future options for ALK-positive non-small cell lung cancer. Lung Cancer. 2015;87(3):211-219.

39. Kanaan Z, Kloecker GH, Paintal A, Perez CA. Novel targeted therapies for resistant ALK-rearranged non-small-cell lung cancer: ceritinib and beyond. Onco Targets Ther. 2015;8:885-892.

40. Crinò L, Kim D, Riely GJ, et al. Initial phase II results with crizotinib in advanced ALK-positive non-small cell lung cancer (NSCLC): PROFILE1005. J Clin Oncol. 2011;29(suppl):7514.

41. Kim D, Ahn M, Shi Y, et al. Updated results of a global phase II study with crizotinib in advanced ALK positive NSCLC. Ann Oncol. 2012; 23(suppl 9):402.

42. Ou SH, Bartlett CH, Mino-Kenudson M, Cui J, Iafrate AJ. Crizotinib for the treatment of ALK-rearranged non-small cell lung cancer: a success story to usher in the second decade of molecular targeted therapy in oncology. Oncologist. 2012;17(11):1351-1375.

43. Toyokawa G, Seto T. ALK inhibitors: what is the best way to treat patients with ALK+ non-small-cell lung cancer? Clin Lung Cancer. 2014; 15(5):313-319.

44. Solomon BJ, Mok T, Kim DW, et al; PROFILE 1014 Investigators. First-line crizotinib versus chemotherapy in ALK-positive lung cancer. N Engl J Med. 2014;371(23):2167-2177.

45. Bergethon K, Shaw AT, Ou SH, et al. ROS1 rearrangements define a unique molecular class of lung cancers. J Clin Oncol. 2012;30(8): 863-870

46. Shaw AT, Ou SH, Bang YJ, et al. Crizotinib in ROS1-rearranged nonsmall-cell lung cancer. N Engl J Med. 2014;371(21):1963-1971.

47. Pailler E, Auger N, Lindsay CR, et al. High level of chromosomal instability in circulating tumor cells of ROS1-rearranged non-small-cell lung cancer. Ann Oncol. 2015;26(7):1408-1415.

48. Scheffler M, Schultheis A, Teixido C, et al. ROS1 rearrangements in lung adenocarcinoma: prognostic impact, therapeutic options and genetic variability. Oncotarget. 2015;6(12):10577-10585.

49. Choi YL, Soda M, Yamashita Y, et al; ALK Lung Cancer Study Group. EML4-ALK mutations in lung cancer that confer resistance to ALK inhibitors. N Engl J Med. 2010;363(18):1734-1739.

50. Katayama R, Khan TM, Benes C, et al. Therapeutic strategies to overcome crizotinib resistance in non-small cell lung cancers harboring the fusion oncogene EML4-ALK. Proc Natl Acad Sci U S A. 2011; 108(18):7535-7540.
51. Okamoto I, Nakagawa K. Echinoderm microtubule-associated proteinlike 4-anaplastic lymphoma kinase-targeted therapy for advanced non-small cell lung cancer: molecular and clinical aspects. Cancer Sci. 2012;103(8):1391-1396.

52. Sasaki T, Koivunen J, Ogino A, et al. A novel ALK secondary mutation and EGFR signaling cause resistance to ALK kinase inhibitors. Cancer Res. 2011;71(18):6051-6060.

53. Katayama R, Shaw AT, Khan TM, et al. Mechanisms of acquired crizotinib resistance in ALK-rearranged lung cancers. Sci Transl Med. 2012;4(120):120ra17.

54. Doebele RC, Pilling AB, Aisner DL, et al. Mechanisms of resistance to crizotinib in patients with ALK gene rearranged non-small cell lung cancer. Clin Cancer Res. 2012;18(5):1472-1482.

55. Friboulet L, Li N, Katayama R, et al. The ALK inhibitor ceritinib overcomes crizotinib resistance in non-small cell lung cancer. Cancer Discov. 2014;4(6):662-673.

56. Shaw AT, Kim DW, Mehra R, et al. Ceritinib in ALK-rearranged nonsmall-cell lung cancer. N Engl J Med. 2014;370(13):1189-1197.

57. Nishio M, Murakami H, Horiike A, et al. Phase I study of ceritinib (LDK378) in Japanese patients with advanced, anaplastic lymphoma kinase-rearranged non-small-cell lung cancer or other tumors. J Thorac Oncol. 2015;10(7):1058-1066.

58. Seto T, Kiura K, Nishio M, et al. CH5424802 (RO5424802) for patients with ALK-rearranged advanced non-small-cell lung cancer (AF-001JP study): a single-arm, open-label, phase 1-2 study. Lancet Oncol. 2013;14(7):590-598.

59. Toyokawa G, Seto T, Takenoyama M, Ichinose Y. Insights into brain metastasis in patients with ALK+ lung cancer: is the brain truly a sanctuary? Cancer Metastasis Rev. Epub 2015 Sep 5.

60. Liao BC, Lin CC, Shih JY, Yang JC. Treating patients with ALKpositive non-small cell lung cancer: latest evidence and management strategy. Ther Adv Med Oncol. 2015;7(5):274-290.

61. Brahmer J, Reckamp KL, Baas P, et al. Nivolumab versus docetaxel in advanced squamous-cell non-small-cell lung cancer. $N$ Engl J Med. 2015;373(2):123-135.

62. Pillai RN, Ramalingam SS. Heat shock protein 90 inhibitors in nonsmall-cell lung cancer. Curr Opin Oncol. 2014;26(2):159-164.

\section{Publish your work in this journal}

Drug Design, Development and Therapy is an international, peerreviewed open-access journal that spans the spectrum of drug design and development through to clinical applications. Clinical outcomes, patient safety, and programs for the development and effective, safe, and sustained use of medicines are a feature of the journal, which

\section{Dovepress}

has also been accepted for indexing on PubMed Central. The manuscript management system is completely online and includes a very quick and fair peer-review system, which is all easy to use. Visit http://www.dovepress.com/testimonials.php to read real quotes from published authors. 